\title{
Short-Chain Specific Acyl-CoA Dehydrogenase, Mitochondrial
}

National Cancer Institute

\section{Source}

National Cancer Institute. Short-Chain Specific Acyl-COA Dehydrogenase, Mitochondrial. NCI Thesaurus. Code C82876.

Short-chain specific acyl-CoA dehydrogenase, mitochondrial (412 aa, $\sim 44 \mathrm{kDa}$ ) is encoded by the human ACADS gene. This protein plays a role in the oxidation of lipids. 